\title{
THE OCCURRENCE OF SEMINAL PLASMA ANTIGENS IN THE TISSUES OF WOMEN
}

\author{
SALLY R. DE FAZIO AND M. M. KETCHEL \\ Department of Physiology, Tufts University School of Medicine, \\ Boston, Massachusetts 02111, U.S.A.
}

(Received 8th Fune 1971, accepted 7th September 1971)

\begin{abstract}
Summary. Extracts of tissues and secretions of women were examined by immunoelectrophoresis with an antiserum against human seminal plasma. Of the twenty-three detected seminal plasma antigens, seven were found in blood serum, and ten antigens not detected in blood serum were found in other female tissues and secretions. Milk was found to contain one non-serum seminal plasma antigen; saliva, urine, vagina and ovary each contained two; cervical mucus and kidney each contained three; nasal secretion, cervix, endometrium, and Fallopian tubes each contained four; and gastric fluid contained five such antigens. It is suggested that women may avoid adverse immunological reactions to seminal plasma because its antigens are not foreign to them.
\end{abstract}

\section{INTRODUCTION}

Seminal plasma antigens have been considered to consist of blood plasma proteins and 'seminal plasma specific' proteins. Since female animals can be sensitized to foreign antigens by way of their reproductive tracts (Strauss, 1961; Bell \& Wolf, 1967), they would be expected to become sensitized to seminal plasma specific proteins by insemination. The failure of female rabbits to respond immunologically to injected rabbit seminal plasma led Menzoian \& Ketchel (1966) to suggest that females may escape sensitization to seminal plasma proteins because these proteins are produced in the female reproductive tract. This hypothesis was confirmed in part by our finding that human cervical mucus contains three seminal plasma antigens which are not found in blood serum (De Fazio \& Ketchel, 1971).

The present investigation extends the search for seminal plasma specific antigens to other female and male tissues and body fluids. Other reports dealing with the specificity of the antigens of seminal plasma have only compared seminal plasma to a limited variety of organs and secretions (Shulman, Riera \& Yantorno, 1968; Quinlivan, 1969). Cross-reactivity of the non-serum components of seminal plasma has been positively established only for lactoferrin (Hekman \& Rumke, 1969) and for two antigens of kidney (Herrmann, 1968).

\section{Seminal plasma}

\section{MATERIALS AND METHODS}

Eight healthy young men each provided a series of semen samples. The donors were asked to abstain from sexual activity for 3 days before submitting 
samples. Immediately after collection, the samples were refrigerated and were then centrifuged within a few hours to remove spermatozoa and detritus, and stored at $-20^{\circ} \mathrm{C}$.

\section{Serum}

Semen donors and other volunteers provided blood samples. Serum was decanted from clotted blood and stored at $-20^{\circ} \mathrm{C}$.

\section{Milk}

Milk, collected from a woman nursing a baby, was immediately refrigerated. Several hours later, it was frozen at $-20^{\circ} \mathrm{C}$.

\section{Urine}

Urine was collected from three young women and one young man. After centrifugation to remove débris, each sample was dialysed overnight against tris buffer $\left(0.01 \mathrm{~m}, \mathrm{pH} \mathrm{7.2)}\right.$ at $4^{\circ} \mathrm{C}$. The dialysed samples were then concentrated approximately 100 times with Lyphogel (Gelman Instrument Co.). Similar treatment was applied to two samples of bladder urine, obtained from two 70year-old women, both free of urinary tract infection, who were catheterized while attending the Pratt Diagnostic Clinic, Tufts-New England Medical Center.

\section{Saliva}

Three young women and one young man, who were free of periodontal disease, provided specimens of saliva by spitting into a beaker, no artificial stimulation of flow being used. The specimens were cooled to $4^{\circ} \mathrm{C}$, concentrated five to ten times with Lyphogel, and used immediately for immunoelectrophoresis.

\section{Nasal secretions}

Nasal mucus was collected from three young women and one young man who were asked to blow their noses into sheets of Parafilm. The samples were refrigerated until used for immunoelectrophoresis on the day of collection.

\section{Gastric secretions}

Gastric fluid samples collected by stomach tube from four women were provided by the Gastroenterology Service, Tufts-New England Medical Center. Samples were taken without stimulation of secretion or regard to contamination by saliva. The samples were refrigerated immediately and dialysed at $4^{\circ} \mathrm{C}$ against tris buffer $(0.01 \mathrm{M}, \mathrm{pH} 7.2)$ on the day of collection. Dialysis was continued for $48 \mathrm{hr}$. Each specimen was concentrated approximately ten times with Lyphogel and stored at $-20^{\circ} \mathrm{C}$.

\section{Human tissues}

Autopsy and surgical specimens were received from the Department of Pathology, Tufts-New England Medical Center, usually within $12 \mathrm{hr}$ post mortem or within $8 \mathrm{hr}$ after surgery. 
Saline extracts of tissues for immunoelectrophoretic analysis were prepared by removing fat and connective tissue, mincing the tissue with scissors, and homogenizing it with an equal volume of cold saline in a Potter-Elvehjem biohomogenizer until macroscopic pieces were dispersed. The homogenate was centrifuged at $1000 \mathrm{~g}$ for $20 \mathrm{~min}$, and the supernatant was stored at $-20^{\circ} \mathrm{C}$ until use.

\section{Antiserum to human seminal plasma}

Equal volumes of seminal plasma were pooled from three donors who, when considered together, had in their seminal plasma all of the antigens we have been able to detect (De Fazio, Lewis \& Ketchel, 1969; De Fazio \& Ketchel, 1971). Three rabbits were injected intramuscularly three times/week for 2 weeks with $0.5 \mathrm{ml}$ seminal plasma emulsified with $0.5 \mathrm{ml}$ Freund's complete adjuvant. The rabbits were injected with $0.5 \mathrm{ml}$ seminal plasma without adjuvant 2 weeks after the last injection, and 2 days later they were bled.

\section{Absorbed antiserum to human seminal plasma}

Antibodies to antigens that could be detected in both seminal plasma and some other body fluid were removed from antiserum to seminal plasma by absorption before the use of the antiserum for immunoelectrophoresis. One vol. antiserum and one vol. absorbing fluid were mixed and incubated for $18 \mathrm{hr}$ at $4^{\circ} \mathrm{C}$. The precipitate that formed was removed by centrifugation. Completeness of absorption was checked by subjecting the absorbing fluid to immunoelectrophoresis with the absorbed antiserum.

\section{Immunoelectrophoresis and staining}

Immunoelectrophoresis was performed according to the micromethod of Scheidegger (1955). Microscope slides were coated with $1 \%$ agarose in barbital buffer ( $\mathrm{pH} 8.2$; ionic strength 0.025 ). Electrophoresis was carried out for 30 $\min$ at $34 \mathrm{~mA}$. Generally, $0.002 \mathrm{ml}$ of undiluted seminal plasma or blood serum, or $0.006 \mathrm{ml}$ of other fluid, was placed in the antigen well. Following electrophoresis, $0.1 \mathrm{ml}$ antiserum was placed in the trough, and the slides were placed in a moist chamber for $24 \mathrm{hr}$ to permit the development of precipitin bands. Slides were then washed overnight with agitation in saline, dried under filter paper, and stained. A stain for proteins composed of $0.1 \%$ amidoschwartz, $0.1 \%$ light green $\mathrm{SF}$, and $0.1 \%$ thiazine red $\mathrm{R}$ in $2 \%$ acetic acid was used.

Precipitin lines were also stained by the periodic acid-Schiff method (Uriel, 1964), by the Gomori method for acid phosphatase (Shulman, Mamrod, Gonder \& Soanes, 1964), by the Prussian blue reaction for iron (Pearse, 1961), and by methods for non-specific esterase (Matilla, Racenia \& Carmi, 1967) and 'leucine aminopeptidase' (Herrmann, 1968).

The technique of Osserman (1960) was used to determine identity between antigens in seminal plasma and other tissues and secretions. Immunoelectrophoresis was carried out in the usual manner but, after electrophoresis, a second trough was cut parallel to the first filled with the tissue extract or body fluid. Antibodies in the anti-seminal plasma antiserum reacted with antigens in the second trough, forming a series of straight lines between and parallel to 
the troughs. When one of the antigens forming such lines was identical to an antigen in seminal plasma, the straight line merged with the precipitin band produced by that antigen.

\title{
RESULTS
}

We recently reported (De Fazio et al., 1969) that immunoelectrophoresis revealed nineteen antigens in human seminal plasma. In the present experiments, the number of detected antigens was extended to twenty-three (Text-fig. 1 ). The increase is accounted for by (1) the development of a better quality antiserum, (2) extension of the antiserum trough so that bands which migrate toward the cathode are demonstrated, and (3) the utilization of several additional staining techniques on the slides following immunoelectrophoresis.

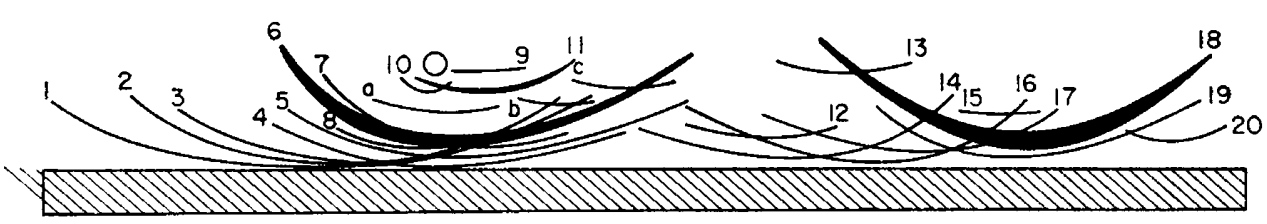

\begin{abstract}
TEXT-FIG. 1. A composite diagram of the human seminal plasma antigens that could be demonstrated by immunoelectrophoresis using antisera to human seminal plasma. Well, seminal plasma; trough, antiserum to seminal plasma. Bands marked $a, b$ and $c$ represent non-specific esterase A, non-specific esterase B and 'leucine aminopeptidase', respectively.
\end{abstract}

Although a total of twenty-three antigens could be detected in the seminal plasma of the eight men, only eighteen to twenty-one antigens could be detected in the seminal plasma of any one individual. Inter-individual differences were seen as reported earlier (De Fazio et al., 1969).

A variety of stains was used to visualize the antigens. Twenty bands could be detected using the protein stain. Of these, Band 9 could also be stained with the PAS reaction, Band 11 with the Prussian blue reaction for iron, Band 15 with the 'leucine aminopeptidase' reaction, and Band 16 with the Gomori stain for acid phosphatase. The staining of Band 16 by the Gomori stain could be completely inhibited with L-tartrate, which is known to inhibit prostatic but not erythrocytic acid phosphatase (Abul-Fadl \& King, 1949). In addition to the twenty bands detected with the protein stain, three bands were revealed with other staining techniques. Two of these stained with a non-specific esterase reaction and one with the 'leucine aminopeptidase' reaction. Those precipitin bands which react with other than the protein stain are indicated in Table 1.

The technique of Osserman (1960) was used in order to determine which of the precipitin bands of seminal plasma represented blood serum proteins. Straight precipitin bands formed lines of identity with seminal plasma Bands 1, $5,8,13,17$ and 18 , indicating that these seminal plasma antigens also occurred in blood serum. By absorbing antiserum to seminal plasma with blood serum, these precipitin bands disappeared, corroborating their presence in blood serum. Antibody to Band 20 could also be absorbed out with blood serum, indicating that it, too, is a serum protein. 
The Osserman technique was also utilized in an experiment in which blood serum was placed in the wells, with an antiserum to human serum in one trough and seminal plasma in the other. Reactions of identity were established with precipitin arcs showing the characteristic shapes and positions of albumin, transferrin and immunoglobulin G. Because of the complexity of the pattern produced, the identities of three other arcs reacting with seminal plasma were less easily established. They appeared to be $\alpha_{1}$ antitrypsin, $\alpha_{1}$ glycoprotein and $\alpha_{1 \times}$ glycoprotein. Seminal plasma was tested against specific antisera to $\alpha_{1}$

TABLe 1

SPECIFICITY OF HUMAN SEMINAL PLASMA ANTIGENS

\begin{tabular}{|c|c|c|c|}
\hline Band no. & $\begin{array}{l}\text { Probable identity or } \\
\text { histochemical reaction }\end{array}$ & $\begin{array}{c}\text { Frequency in } \\
\text { the seminal } \\
\text { plasma of eight } \\
\text { donors }\end{array}$ & Also found in: \\
\hline $\begin{array}{r}1 \\
2 \\
3 \\
4 \\
5 \\
6 \\
7 \\
8 \\
9 \\
10 \\
11 \\
12 \\
13 \\
14 \\
15 \\
16 \\
17 \\
18 \\
19 \\
20\end{array}$ & $\begin{array}{l}\text { Immunoglobulin G } \\
\text { Unknown } \\
\text { Unknown } \\
\text { Unknown } \\
\text { Immunoglobulin A? } \\
\text { Unknown } \\
\text { Unknown } \\
\text { Transferrin? } \\
\text { PAS-positive } \\
\text { Unknown } \\
\text { Lactoferrin } \\
\text { Unknown } \\
\alpha_{1 \times} \text { Glycoprotein } \\
\text { Unknown } \\
\text { 'Leucine aminopeptidase' } \\
\text { Prostatic acid phosphatase } \\
\alpha_{1} \text { Antitrypsin } \\
\text { Serum albumin } \\
\text { Unknown } \\
\text { Prealbumin ? } \\
\text { Non-specific esterase A } \\
\text { Non-specific esterase B } \\
\text { 'Leucine aminopeptidase' }\end{array}$ & $\begin{array}{l}3 / 8 \\
8 / 8 \\
7 / 8 \\
8 / 8 \\
5 / 8 \\
8 / 8 \\
7 / 8 \\
8 / 8 \\
8 / 8 \\
3 / 8 \\
8 / 8 \\
6 / 8 \\
8 / 8 \\
8 / 8 \\
8 / 8 \\
8 / 8 \\
4 / 8 \\
8 / 8 \\
4 / 8 \\
8 / 8 \\
8 / 8 \\
1 / 8 \\
8 / 8\end{array}$ & $\begin{array}{l}\text { S* } \\
\text { N } \\
\text { CM (Band II), C, O } \\
\text { K } \\
\text { S } \\
\text { C, E, G, V } \\
\text { C, CM (Band IV), E, F, O } \\
\text { S } \\
\text { G, E, F, G, M, N, Sa } \\
\text { S } \\
\text { E, F, G, N, Sa, U } \\
\text { K } \\
\text { S } \\
\text { S } \\
\text { G } \\
\text { S } \\
\\
\text { K, U }\end{array}$ \\
\hline
\end{tabular}

$\mathrm{C}=$ cervix, $\mathrm{CM}=$ cervical mucus, $\mathrm{E}=$ endometrium, $\mathrm{F}=$ Fallopian tube, $\mathrm{G}=$ gastric fluid, $\mathrm{K}=$ kidney, $\mathrm{M}=$ milk, $\mathrm{N}=$ nasal secretion, $\mathrm{O}=$ ovary, $\mathrm{S}=$ serum, $\mathrm{Sa}=$ saliva, $\mathrm{U}=$ urine, $\mathrm{V}=$ vaginal mucosa.

* Many of the serum proteins in seminal plasma were also found in the other secretions and tissue extracts studied here.

antitrypsin and transferrin, and showed faint precipitin bands with each antiserum. Table 1 indicates the identities of the blood serum proteins which occur in seminal plasma.

In order to determine if the non-serum antigens of seminal plasma occur elsewhere in women, a number of human secretions and tissue extracts were compared to seminal plasma by immunoelectrophoresis. While many of these fluids and extracts contained blood serum antigens, most of them also contained non-serum antigens which could be demonstrated with antiserum to seminal plasma that had been absorbed with blood serum. The identities of the antigens in the fluid and tissue extracts were established by the Osserman 
technique (see Pl. 1, Figs. $l$ and 2) and corroborated, where possible, by absorption studies. The results, summarized in Table 2, show the presence of at least one non-blood seminal plasma antigen in each tissue or body fluid examined except liver and muscle. Seminal plasma Band 11, lactoferrin, occurred in all other tissues and body fluids examined except kidney and ovary. Male saliva, nasal secretions and urine contained the same seminal plasma antigens as did female saliva, nasal secretion and urine.

TABLE 2

NON-SERUM SEMINAL PLASMA ANTIGENS IN HUMAN SECRETIONS

\begin{tabular}{|c|c|c|c|}
\hline $\begin{array}{l}\text { Secretion or } \\
\text { tissue extract }\end{array}$ & $\begin{array}{c}\text { No. of samples } \\
\text { and } \\
\text { sex of donor }\end{array}$ & Seminal plasma Band no. & $\begin{array}{c}\text { Identity* } \\
\text { established by: }\end{array}$ \\
\hline $\begin{array}{l}\text { Milk } \\
\text { Urine } \\
\text { Saliva } \\
\text { Nasal secretion } \\
\text { Gastric fluid } \\
\text { Cervical mucus } \\
\text { Cervix } \\
\text { Endometrium } \\
\text { Fallopian tube } \\
\text { Vagina } \\
\text { Kidney } \\
\text { Ovary } \\
\text { Liver } \\
\text { Muscle }\end{array}$ & $\begin{array}{l}1 \mathrm{~F} \\
4 \mathrm{~F}, 1 \mathrm{M} \\
3 \mathrm{~F}, 1 \mathrm{M} \\
3 \mathrm{~F}, 1 \mathrm{M} \\
4 \mathrm{~F} \\
22 \mathrm{~F} \\
4 \mathrm{~F} \\
4 \mathrm{~F} \\
2 \mathrm{~F} \\
1 \mathrm{~F} \\
2 \mathrm{~F}, 1 \mathrm{M} \\
1 \mathrm{~F} \\
1 \mathrm{M} \\
1 \mathrm{M}\end{array}$ & $\begin{array}{l}11 \\
14, \text { 'leucine aminopeptidase' } \\
11,14 \\
2,7,11,14 \\
6 \text { (1 sample) }, 7,11,14,19 \text { (1 sample) } \\
3 \text { (2 samples),7,11 } \\
3,6,7,11 \text { (1 sample) } \\
6,7,11 \text { (1 sample),14 } \\
6 \text { (1 sample), } 7,11 \text { (1 sample), } 14 \\
6,11 \\
4, \text { 'leucine aminopeptidase,' } 15 \\
3,7 \\
\text { None } \\
\text { None }\end{array}$ & $\begin{array}{l}\text { P,O } \\
\text { P, A, S } \\
\text { P, O, A } \\
\text { P, O, A } \\
\text { O } \\
\text { P, O } \\
\text { O } \\
\text { O } \\
\text { O } \\
\text { P, O, S, A } \\
\text { O } \\
=\end{array}$ \\
\hline
\end{tabular}

* Immunochemical identities of these antigens were established by-P: immunoelectrophoretic position; O: Osserman technique; A: absorption of antibodies to the antigen; $\mathrm{S}$ : special staining technique.

\section{DISGUSSION}

Of the twenty-three seminal plasma antigens detected, seven were found to be immunologically identical to blood serum proteins and ten were found to be identical to antigens of the tissues or secretions of at least one woman. While six seminal plasma antigens have not yet been located in the female, and some of the seventeen seminal plasma antigens found in females were not detected in all females, the present data suggest that females do not become sensitized to seminal plasma proteins because such proteins are recognized as 'self'. Further studies will be necessary to confirm this concept.

It has been suggested that the development of autoimmune aspermatogenesis is possible only because some of the sperm antigens are not present when the immune system of the developing male is establishing which antigens are recognized as 'self' (Pirofsky, 1969). It is, therefore, interesting that only one of the seventeen seminal plasma antigens found in the female was located solely in reproductive tract material, and that some seminal plasma antigens appear to be characteristic of other human secretions. This means that for those seminal plasma antigens which occur in tissues other than the reproductive tract, the problem of acquiring tolerance to them after puberty is alleviated.

It seems more likely that women can escape sensitization to seminal plasma 
PLATE 1

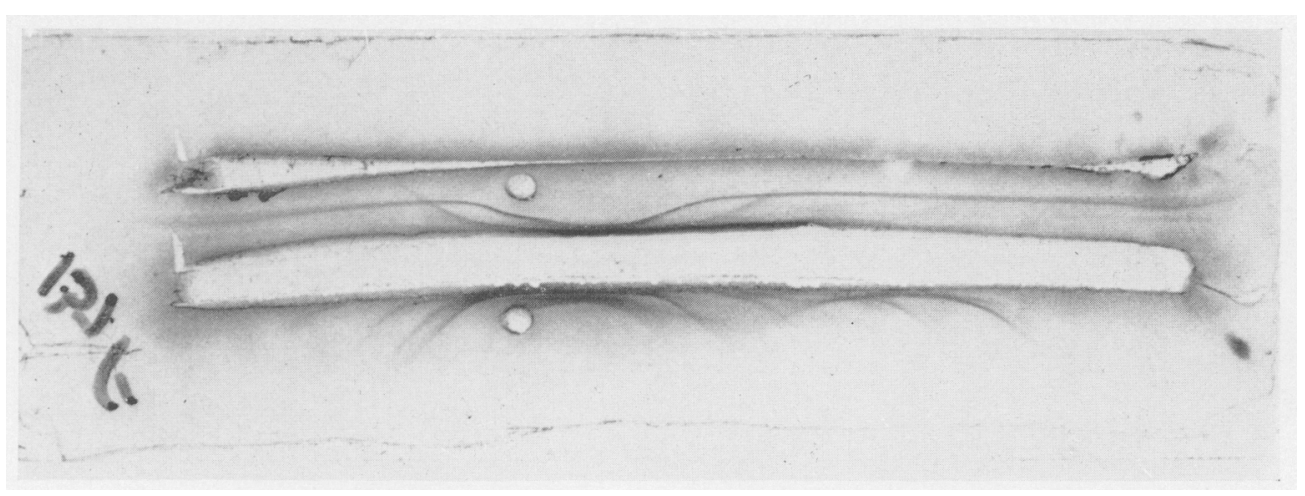

FIG. 1. A photograph illustrating the use of the Osserman technique. Upper trough, extract of cervix; lower trough, antiserum to seminal plasma; antigen wells, seminal plasma. Only the reaction with Band 11 was intense enough to photograph well. Curvature of the troughs is an artifact of drying.
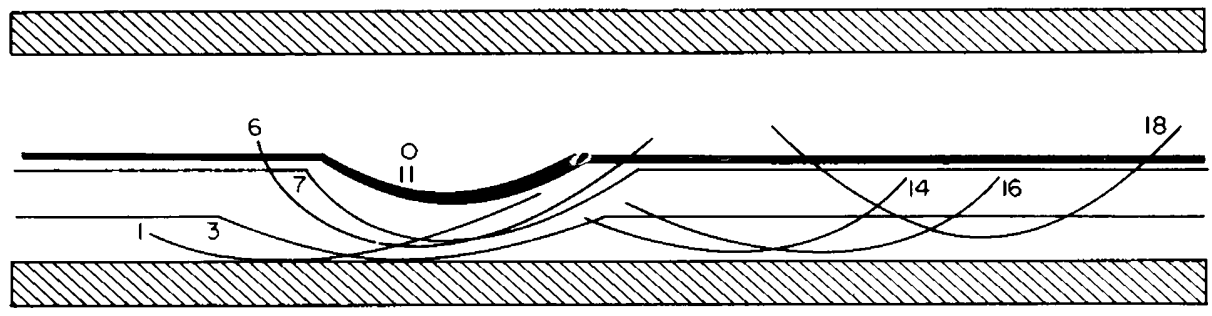

Fig. 2. A diagram illustrating the use of the Osserman technique. Upper trough, extract of cervix; lower trough, antiserum to seminal plasma; antigen well, seminal plasma. The extract sample in the upper trough is shown giving reactions of identity with seminal plasma Bands 3, 7 and 11. Some of the seminal plasma bands have been omitted for clarity. 
by recognizing its antigens as 'self' if the antigens are relatively few in number and are constant in different males. As we reported earlier (De Fazio et al., 1969), no variation could be found in the seminal plasma of any one man with time or increased sexual activity, and the inter-individual differences appeared relatively minor. While the antigens that varied between individuals include three of the six which have not yet been located in the female, they also include antigens which could be found in blood serum and other female tissues. Thus, a woman's recognition as 'self' seems to extend to variable antigens as well as antigens which are found in the seminal plasma of most men.

\section{ACKNOWLEDGMENTS}

The authors wish to thank Dr Edward MacMahon and members of the Department of Pathology, Tufts-New England Medical Center for providing tissue specimens; Dr George Mitchell, for providing urine samples; and Dr James Patterson for providing gastric fluid samples.

This work was supported by a National Institute of Health Training Grant number 5T 01 AM 5220-10.

\section{REFERENCES}

Abuz-Fadi, M. A. M. \& King, E. J. (1949) Properties of the acid phosphatases of erythrocytes and of the human prostate gland. Biochem. 7. 45, 51 .

BeLl, E. B. \& WoLF, B. (1967) Antibody synthesis in vitro by the rabbit vagina against diph theria toxoid. Nature, Lond. 214, 423.

De Fazio, S. R. \& Ketchel, M. M. (1971) Immunoelectrophoretic analysis of human cervical mucus and seminal plasma with antiserum to cervical mucus. $\mathcal{F}$. Reprod. Fert. 25, 11.

De Fazio, S., Lewis, B. K. \& Ketchel, M. M. (1969) Antigenic variations in the seminal plasma of different men. F. Reprod. Fert. $20,29$.

Hekman, A. \& Rümke, P. (1969) The antigens of human seminal plasma with special reference to lactoferrin as a spermatozoa-coating antigen. Fert. Steril. 20, 312.

Herrmann, W. P. (1968) Immunologische Charakterisierung der Aminopeptidasen im menschlichen Spermaplasma. Arch. klin. exp. Derm. 233, 269.

Matilla, S. P., Racenia, V. K. \& Carmi, T. K. I. (1967) An immunoelectrophoretic study of the soluble antigens of the human prostate. 7 . Urol. $97,117$.

Menzoian, J. O. \& Ketchel, M. M. (1966) Immunological tolerance of the female to homologous seminal plasma protein. Nature, Lond. 211, 133.

Osserman, E. F. (1960) A modified technique of immunoelectrophoresis facilitating the identification of specific precipitin arcs. F. Immun. 84, 93.

Pearse, A. G. E. (1961) Histochemistry, 2nd edn. Little Brown, Boston.

Pirofsky, B. (1969) The self-recognition phenomenon and autoimmunization. In: Autoimmunization and the Autoimmune Hemolytic Anemias, p. 313. Williams \& Wilkins, Baltimore.

Quinlivan, W. L. (1969) The specific antigens of human seminal plasma. Fert. Steril. 20, 58.

ScheIdegGer, J. J. (1955) Une micro-méthode de l'immunoélectrophorèse. Int. Archs Allergy appl. Immun. 7, 103.

Shulman, S., Mamrod, L., Gonder, M. J. \& Soanes, W. A. (1964) The detection of prostatic acid phosphatase by antibody reactions in gel diffusion. 7. Immun. 93, 474.

Shulman, S., Riera, G. \& Yantorno, C. (1968) Studies on organ specificity. XIX. Antigenic specificity of seminal plasma and the formation of autoantibodies. $\mathcal{F}$. Immun. 100, 682.

Strauss, E. K. (1961) Occurrence of antibody in vaginal mucus. Proc. Soc. exp. Biol. Med. 106, 617.

URIEL, J. (1964) Characterization reactions of proteins. In: Immunoelectrophoretic Analysis, p. 30 . Eds. P. Graber and P. Burtin. Elsevier Publishing Company, Amsterdam. 